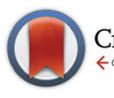

CrossMark

\& click for updates

Cite this: Dalton Trans., 2014, 43

14514

Received 25th July 2014,

Accepted 13th August 2014

DOI: $10.1039 / c 4 d t 02265 c$

www.rsc.org/dalton

\section{The preparation and structure of $\mathrm{Ge}_{3} \mathrm{~F}_{8}-$ a new mixed-valence fluoride of germanium, a convenient source of $\mathrm{GeF}_{2} \dagger$}

\author{
Andrew L. Hector, Andrew Jolleys, William Levason, * David Pugh and Gillian Reid
}

\begin{abstract}
The new binary mixed-valence fluoride of germanium, $\mathrm{Ge}_{3} \mathrm{~F}_{8}$, has been obtained by heating $\mathrm{GeF}_{4}$ with powdered $\mathrm{Ge}$ in an autoclave (390 K/4 bar/48 h). The structure contains pyramidal $\mathrm{Ge}^{\prime \prime} \mathrm{F}_{3}$ and octahedral $\mathrm{Ge}^{\mathrm{IV}} \mathrm{F}_{6}$ units, linked by fluoride bridges. The new compound is the missing member of the series $\left(\mathrm{GeF}_{2}\right)_{n} \cdot \mathrm{GeF}_{4}(n=2,4$, or 6). Sublimation of $\left(\mathrm{GeF}_{2}\right)_{n} \cdot \mathrm{GeF}_{4}$ in vacuo provides a convenient source of $\mathrm{GeF}_{2}$ in ca. $30 \%$ overall yield.
\end{abstract}

Although germanium is technologically very important both as the element and in oxide or chalcogenide compounds, with key applications in electronics, ceramics and optics, ${ }^{1}$ its chemistry was neglected for many years compared with those of silicon and tin. It is now a very active area of main group chemistry and, in addition to the extensive chemistry of $\mathrm{Ge}(\mathrm{Iv}),{ }^{2}$ recent work has identified a large and complex coordination chemistry of $\mathrm{Ge}(\mathrm{II}) ;{ }^{2,3}$ the latter contrasting with the limited coordination chemistry of $\mathrm{Si}(\mathrm{II}) .^{2}$ In Group 14 as well as the common tetrahalides $\mathrm{MX}_{4}(\mathrm{M}=\mathrm{Si}, \mathrm{Ge}, \mathrm{Sn} ; \mathrm{X}=\mathrm{F}-\mathrm{I}),{ }^{4}$ there are dihalides $\mathrm{MX}_{2}(\mathrm{M}=\mathrm{Ge}, \mathrm{Sn})$, and the subhalides, $\mathrm{GeBr}$ and SnBr. ${ }^{5}$ Of these, the chemistry of $\mathrm{GeF}_{2}$ has been very little explored since it is not readily available commercially and its preparation by repeatedly passing $\mathrm{GeF}_{4}$ over heated germanium, is both inconvenient and time consuming, ${ }^{6}$ while the alternative method, involving the reaction of Ge with anhydrous $\mathrm{HF}$ in an autoclave, is hazardous. Both routes also require special equipment. ${ }^{7}$ A number of intermediate halides have also been identified. ${ }^{2}$ The latter are of two types; the most common are those with element-element (E-E) bonds, including $\mathrm{Si}_{2} \mathrm{~F}_{6}, \mathrm{Si}_{2} \mathrm{Cl}_{6}, \mathrm{Si}_{3} \mathrm{Cl}_{8}, \mathrm{Si}_{6} \mathrm{Cl}_{14}, \mathrm{Ge}_{2} \mathrm{Cl}_{6}$ and $\mathrm{Ge}_{5} \mathrm{Cl}_{12},{ }^{8}$ with structures analogous to the corresponding alkanes. Much

Chemistry, University of Southampton, Southampton SO17 1BJ, UK.

E-mail: wxl@soton.ac.uk; Tel: +44 (0)2380 593792

$\dagger$ Electronic supplementary information (ESI) available: Experimental details for the syntheses of $\mathrm{Ge}_{3} \mathrm{~F}_{8}$ and $\mathrm{GeF}_{2}$, and the PXRD data for all the products. Further details of the crystal structure investigation may be obtained from Fachinformationszentrum Karlsruhe, 76344 Eggenstein-Leopoldshafen, Germany (fax: (+49)7247-808-666; e-mail: crysdata@fiz-karlsruhe.de, http://www. fiz-karlsruhe.de/request_for_deposited_data.html) on quoting CSD number 427896. See DOI: $10.1039 / \mathrm{c} 4 \mathrm{dt} 02265 \mathrm{c}$ rarer, and limited to Ge and Sn, are a second group of mixedvalence materials, including $\mathrm{Sn}_{3} \mathrm{~F}_{8}, \mathrm{Ge}_{5} \mathrm{~F}_{12}$, and $\mathrm{Ge}_{7} \mathrm{~F}_{16}$, which are without direct E-E bonds, but are fluoride-bridged and contain distinct environments attributable to $\mathrm{M}^{\mathrm{II}}$ and $\mathrm{M}^{\mathrm{IV}}$ centres. ${ }^{9-11}$

We are currently developing new routes for electrodeposition of p-block materials from non-aqueous media, using reagents including halometallate anions as the p-block element source, ${ }^{12}$ and have recently reported the electrochemistry of $\left[\mathrm{GeX}_{3}\right]^{-}(\mathrm{X}=$ $\mathrm{Cl}, \mathrm{Br}$ or I) and $\left[\mathrm{GeCl}_{6}\right]^{2-}$ in $\mathrm{CH}_{2} \mathrm{Cl}_{2}$ solution. ${ }^{13}$ During the course of this work we have extended our studies to the fluoride systems. We report here the preparation and characterisation of a new binary, mixed-valence fluoride of germanium and its use to provide a convenient route to $\mathrm{GeF}_{2}$.

Depending upon the experimental conditions, repeatedly passing $\mathrm{GeF}_{4}$ at low pressure over heated germanium yields either $\mathrm{GeF}_{2},{ }^{6}$ or mixed valence $\mathrm{Ge}^{\mathrm{II}}-\mathrm{Ge}^{\mathrm{IV}}$ fluorides. ${ }^{10,11,14}$ Two of the latter identified by single crystal X-ray diffraction (XRD) studies are $\mathrm{Ge}_{5} \mathrm{~F}_{12} \neq$ and $\mathrm{Ge}_{7} \mathrm{~F}_{16},{ }^{10,11}$ which are members of the series $\left(\mathrm{GeF}_{2}\right)_{n} \cdot \mathrm{GeF}_{4} \cdot{ }^{14}$ These flow reactions are inconvenient and low yielding, hence we have investigated the reduction of $\mathrm{GeF}_{4}$ with $\mathrm{Ge}$ powder in an autoclave under modest pressure ( $390 \mathrm{~K} / 4 \mathrm{bar} / 48 \mathrm{~h}$, see ESI $\dagger$ ). Initial attempts at temperatures $<370 \mathrm{~K}$ resulted in little reaction, but on increasing the temperature to $390 \mathrm{~K} / 48 \mathrm{~h}$, much of the $\mathrm{GeF}_{4}$ was consumed (as indicated by the drop in pressure), and upon opening the autoclave in a glove-box, a mass of white microcrystalline material was found on the cooler lid. The crystals are extremely moisture sensitive, converting into a pool of liquid immediately on exposure to air. Single crystal X-ray diffraction data were collected from one of the small crystals and the structure solution identified this product as $\mathrm{Ge}_{3} \mathrm{~F}_{8}$, the missing third member of the series $\left(\mathrm{GeF}_{2}\right)_{n} \cdot \mathrm{GeF}_{4}$, with $n=2$. Unit cell measurements on several other crystals confirmed these as the same compound. Powder X-ray diffraction (PXRD) data were also collected on the bulk material and that showed smaller amounts of $\mathrm{Ge}_{5} \mathrm{~F}_{12}$ and $\mathrm{Ge}_{7} \mathrm{~F}_{16}$, as well as traces of $\mathrm{GeF}_{2}$ were also present. The simulated and experimental powder XRD data from this mixture are shown in the ESI. $\dagger$ 
Sublimation of the mixture $(390 \mathrm{~K} / 0.5 \mathrm{~mm})$ gave $\sim 30 \%$ yield of $\mathrm{GeF}_{2}$ (based on elemental Ge used in the first step), which was identified by PXRD (see ESI†). Some involatile orange material ( $c f$. ref. 6) was also formed.

Germanium difluoride has a polymeric chain structure based upon trigonal pyramidal $\mathrm{GeF}_{3}$ units $(\mathrm{Ge}-\mathrm{F}=1.79(2)$,

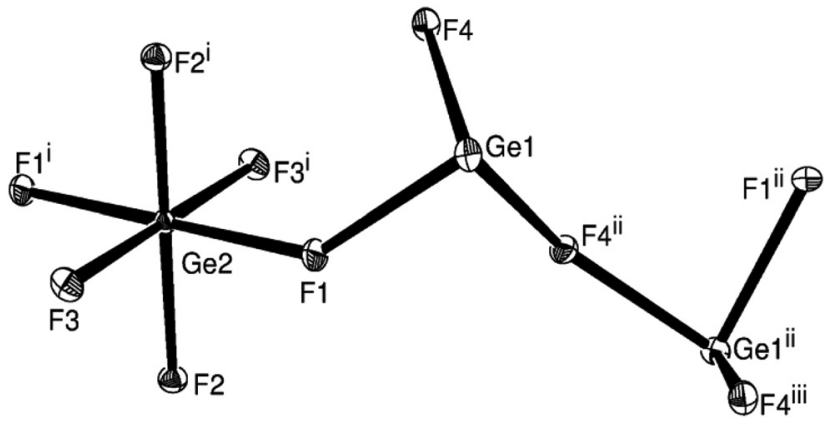

Fig. 1 The $\mathrm{Ge}^{\mathrm{II}}$ and $\mathrm{Ge}^{\mathrm{IV}}$ units in $\mathrm{Ge}_{3} \mathrm{~F}_{8}$ with ellipsoids drawn at the $50 \%$ level. Selected bond lengths $(\AA)$ and angles $\left({ }^{\circ}\right)$ : Ge2-F1 = 1.855(1), Ge2$\mathrm{F} 2=1.767(1), \mathrm{Ge} 2-\mathrm{F} 3=1.782(1), \mathrm{Ge} 1-\mathrm{F} 1=2.010(1), \mathrm{Ge} 1-\mathrm{F} 4 \mathrm{ii}=1.938(1)$, $\mathrm{Ge} 1-\mathrm{F} 4=1.980(1), \mathrm{F} 1-\mathrm{Ge} 1-\mathrm{F} 4=83.28(5), \mathrm{F} 4-\mathrm{Ge}-\mathrm{F} 4 \mathrm{ii}=86.35(3), \mathrm{F} 4 \mathrm{ii}-$ Ge1-F1 $=85.42(6)$. Symmetry codes: (i) $1-x, 1-y, 1-z$; (ii) $0.5-x$, $-0.5+y, 1.5-z$; (iii) $x,-1+y, z$.

(a)
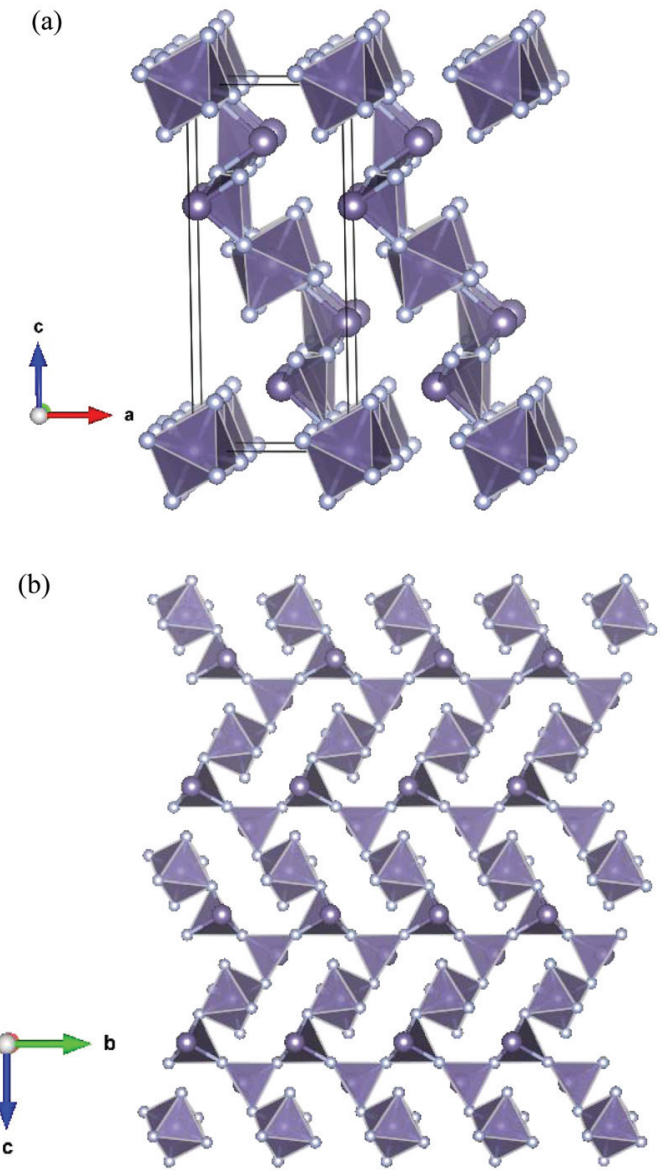

Fig. 2 The $\mathrm{Ge}_{3} \mathrm{~F}_{8}$ structure viewed along: (a) the $b$ axis to observe the sheets, and (b) the $a$ axis, showing the connectivity within the sheets.
1.91(2), 2.09(2) $)$, with a distant fourth fluoride at 2.57(2) $\AA$ that cross-links the chains. ${ }^{15}$ The new preparation is a convenient way to obtain $\mathrm{GeF}_{2}$ in useful quantity for further studies of its coordination and organometallic chemistry.

The single crystals of the mixed-valence $\mathrm{Ge}_{3} \mathrm{~F}_{8}$ are isomorphous with $\mathrm{Sn}_{3} \mathrm{~F}_{8},{ }^{9}$ adopting the monoclinic space group $P 2_{1} / n$. The structure is composed (Fig. 1) of slightly distorted $\mathrm{GeF}_{6}$ octahedra with four terminal Ge-F bonds (1.767(1),

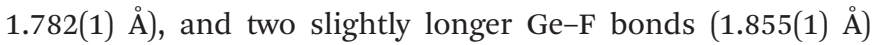
that are involved in bridging to the $\mathrm{Ge}^{\mathrm{II}}$ units. The germanium (II) core environment is trigonal pyramidal, composed of one terminal (Ge-F = 1.938(1) $⿱$ ) $)$ and two bridging $(\mathrm{Ge}-\mathrm{F}=1.980$ (1), 2.010(1) ̊) fluorides, one linked to $\mathrm{Ge}^{\mathrm{IV}}$ and one to a second $\mathrm{Ge}^{\mathrm{II}}$ centre. There are also longer $\mathrm{Ge}^{\mathrm{II}} \cdots \mathrm{F}$ contacts $(2.56 \AA)$, and if these are included, the germanium(II) geometry is a distorted saw-horse shape, reminiscent of $\mathrm{GeF}_{2}$. Overall, the packing is best considered as sheets in the (101) planes (Fig. 2a), with each sheet being made up of puckered chains of $\mathrm{GeF}_{3}$ units along [010] connected together by the $\mathrm{GeF}_{6}$ octahedra (Fig. 2b).

Considering the structures of $\mathrm{Ge}_{5} \mathrm{~F}_{12}{ }^{10}$ and $\mathrm{Ge}_{7} \mathrm{~F}_{16},{ }^{11}$ the same basic building blocks are present (trigonal pyramidal $\mathrm{GeF}_{3}$ and octahedral $\mathrm{GeF}_{6}$ ), but as the $\mathrm{F} / \mathrm{Ge}$ ratio declines, the
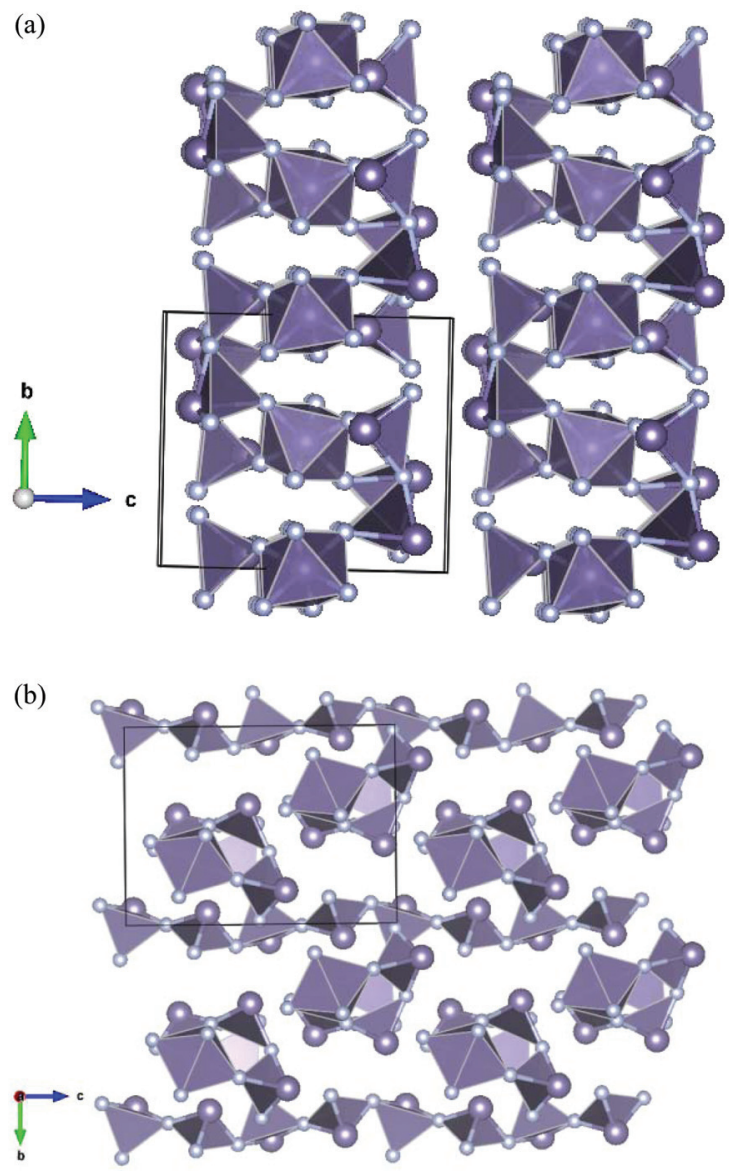

Fig. 3 (a) View of the structure of $\mathrm{Ge}_{5} \mathrm{~F}_{12} \cdot{ }^{10}$ (b) View of the structure of $\mathrm{Ge}_{7} \mathrm{~F}_{16}{ }^{11}$ 
structures become more distorted to maintain the germanium coordination numbers. In $\mathrm{Ge}_{5} \mathrm{~F}_{12}$, if we ignore the distant fourth fluoride at $2.44 \AA$, the $\mathrm{GeF}_{3}$ trigonal pyramids $(\mathrm{Ge}-\mathrm{F}=$ $1.80(2), 1.99(2), 2.20(2) \AA)$ form corrugated sheets in (001), based on $\mathrm{GeF}_{6}$ octahedra linked to dimers of two corner-linked $\mathrm{GeF}_{3}$ pyramids. As a consequence of the $4: 1 \mathrm{Ge}^{\mathrm{II}}: \mathrm{Ge}^{\mathrm{IV}}$ constitution, the $\mathrm{GeF}_{6}$ units are linked to four dimers (rather than two as in $\mathrm{Ge}_{3} \mathrm{~F}_{8}$ ) (Fig. 3a). The structure of $\mathrm{Ge}_{7} \mathrm{~F}_{16}$ is complicated in that there are seven distinct germanium sites, ${ }^{11}$ but again, the building blocks are trigonal pyramidal $\mathrm{GeF}_{3}$ and octahedral $\mathrm{GeF}_{6}$ units. The structure is best described as chains of $\mathrm{GeF}_{3}$ pyramids along [001] with side chains of four $\mathrm{GeF}_{3}$ units terminated by a $\mathrm{GeF}_{6}$ octahedron attached to every second $\mathrm{GeF}_{3}$ of the main chain (Fig. 3b).

In conclusion, the missing member of the unique series of mixed-valence germanium fluorides $\left(\mathrm{GeF}_{2}\right)_{n} \cdot \mathrm{GeF}_{4}(n=2,4$, or 6) has been obtained by reaction of $\mathrm{GeF}_{4}$ and Ge powder under modest pressure and temperature, its structure determined and the structural relationships within the series established. Sublimation of the $\left(\mathrm{GeF}_{2}\right)_{n} \cdot \mathrm{GeF}_{4}$ in vacuo provides a convenient route to the previously rather inaccessible $\mathrm{GeF}_{2}$. Further work to explore the chemistry of $\mathrm{GeF}_{2}$ formed by this route is underway and will be reported in due course.

\section{Acknowledgements}

We thank EPSRC for support (EP/1033394/1 and EP/1010890/1). The SCFED Project (http://www.scfed.net) is a multidisciplinary collaboration of British universities investigating the fundamental and applied aspects of supercritical fluids.

\section{Notes and references}

$\$ \mathrm{Ge}_{5} \mathrm{~F}_{12}$ was originally formulated as $\mathrm{Ge}_{2} \mathrm{~F}_{5},{ }^{14}$ the correct formula subsequently being established from the crystal structure determination. ${ }^{10}$

1 (a) D. D. Vaughn II and R. E. Schaak, Chem. Soc. Rev., 2013, 42, 2861; (b) S. Raoux, W. Welnic and D. Ielmini, Chem. Rev., 2010, 110, 240; (c) D. V. Talapin, J. S. Lee, M. V. Kovalenko and E. V. Shevchenko, Chem. Rev., 2010, 110, 389.

2 (a) J. Parr, in Comprehensive Coordination Chemistry II, ed. J. A. McCleverty and T. J. Meyer, Elsevier, Oxford, 2004, vol. 3, p. 545; (b) W. Levason, G. Reid and W. Zhang, Coord. Chem. Rev., 2011, 255, 1319; (c) N. N. Greenwood and A. Earnshaw, Chemistry of the Elements, Butterworth, Oxford, 2nd edn, 1997; (d) R. S. Ghadwal, H. W. Roesky, S. Merkel, J. Henn and D. Stalke, Angew. Chem., Int. Ed.,
2009, 48, 5683; (e) A. C. Filippou, O. Chernov and G. Schnakenburg, Angew. Chem., Int. Ed., 2009, 48, 5687.

3 For lead references on Ge(II) complexes see: (a) A. J. Arduengo III, H. V. Rasika Dias, J. C. Calabrese and F. Davidson, Inorg. Chem., 1993, 32, 1541; (b) P. A. Rupar, V. N. Staroverov, P. J. Ragogna and K. M. Baines, J. Am. Chem. Soc., 2007, 129, 15138; (c) F. Cheng, A. L. Hector, W. Levason, G. Reid, M. Webster and W. Zhang, Angew. Chem., Int. Ed., 2009, 48, 5152; (d) F. Cheng, J. M. Dyke, F. Ferrante, A. L. Hector, W. Levason, G. Reid, M. Webster and W. Zhang, Dalton Trans., 2010, 39, 847; (e) F. Cheng, A. L. Hector, W. Levason, G. Reid, M. Webster and W. Zhang, Inorg. Chem., 2010, 49, 752; $(f)$ J. England and K. Wieghardt, Inorg. Chem., 2013, 52, 10067; (g) P. A. Rupar, M. C. Jennings and K. M. Baines, Organometallics, 2008, 27, 5043; (h) S. M. I. Al-Rafia, M. R. Momeni, R. McDonald, M. J. Ferguson, A. Brown and E. Rivard, Angew. Chem., Int. Ed., 2013, 52, 6390.

4 A. K. Wolf, J. Glinnemann and M. U. Schmidt, CrystEngComm, 2008, 10, 1364.

5 (a) A. Schnepf and R. Köppe, Z. Anorg. Allg. Chem., 2002, 628, 2914; (b) C. Schrenk, R. Köppe, I. Schellenberg, R. Pöttgen and A. Schnepf, Z. Anorg. Allg. Chem., 2009, 635, 1541.

6 N. Bartlett and K. C. Yu, Can. J. Chem., 1961, 39, 80.

7 E. L. Muetterties, Inorg. Chem., 1962, 1, 342.

8 (a) E. Hengge, in Halogen Chemistry, ed. V. Gutmann, Academic Press, NY, 1967, vol. 2, p. 169; (b) D. Shriver and W. L. Jolly, J. Am. Chem. Soc., 1958, 80, 6692; (c) I. R. Beattie, P. J. Jones, G. Reid and M. Webster, Inorg. Chem., 1998, 37, 6032.

9 M. F. A. Dove, R. King and T. J. King, J. Chem. Soc., Chem. Commun., 1973, 944.

10 J. C. Taylor and P. W. Wilson, J. Am. Chem. Soc., 1973, 95, 1834.

11 J. Köhler and J.-H. Chang, Z. Anorg. Allg. Chem., 1997, 623, 596.

12 (a) P. N. Bartlett, D. Cook, C. H. de Groot, A. L. Hector, R. Huang, A. Jolleys, G. P. Kissling, W. Levason, S. J. Pearce and G. Reid, RSC Adv., 2013, 3, 15645; (b) P. N. Bartlett, D. A. Cook, M. W. George, A. L. Hector, J. Ke, W. Levason, G. Reid, D. C. Smith and W. Zhang, Phys. Chem. Chem. Phys., 2014, 16, 9202.

13 P. N. Bartlett, C. Y. Cummings, W. Levason, D. Pugh and G. Reid, Chem. - Eur. J., 2014, 20, 5019.

14 G. P. Adams, J. L. Margrave and P. W. Wilson, J. Inorg. Nucl. Chem., 1973, 33, 1301.

15 (a) J. Trotter, M. Akhtar and N. Bartlett, J. Chem. Soc. A, 1966, 30; (b) G. Denes, J. Solid State Chem., 1989, 78, 52. 